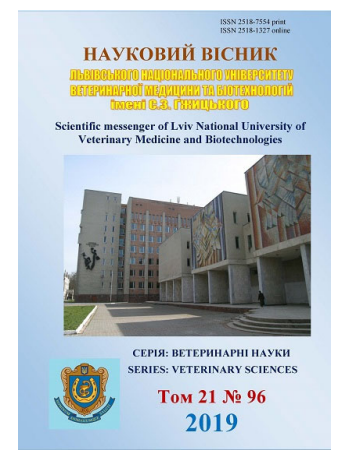

\author{
Науковий вісник Дьвівського національного університету \\ ветеринарної медицини та біотехнологій імені С.3. Гжицького. \\ Серія: Ветеринарні науки \\ Scientific Messenger of Lviv National University \\ of Veterinary Medicine and Biotechnologies. \\ Series: Veterinary sciences
}

\title{
Cellular immunity of rabbits incase of parasite association (Treponema cuniculi and Eimeria sp.)
}

\author{
Y.V. Duda \\ Dnipro State Agrarian and Economic University, Dnipro, Ukraine
}

Article info

Received 28.09.2019

Received in revised form 30.10.2019

Accepted 31.10.2019

Dnipro State Agrarian and Economic University, Yefremov Str., 25, Dnipro, 49027, Ukraine Tel.: +38-067-781-54-69 E-mail:dudajulia1976@gmail.com
Duda, Y.V. (2019). Cellular immunity of rabbits incase of parasite association (Treponema cuniculi and Eimeria sp.). Scientific Messenger of Lviv National University of Veterinary Medicine and Biotechnologies. Series: Veterinary sciences, 21(96), 8-13. doi: 10.32718/nvlvet 9602

Despite a huge number of studies, the uniqueness of antiparasitic immunity is so great that there is still insufficient knowledge of the factors contributing to the manifestation of the characteristics of immunity in mixed parasitic diseases of rabbits. Therefore, the question of the influence of the association of pathogens Treponema cuniculi and Eimeria sp. on indicators of cellular immunity of rabbits is relevant. The study was conducted on 59 male rabbits age 3-5 months of the Californian breed, selected by analogy. Animal were separated into two groups: healthy animals (control group) and sick animals (research group). Intensity of invasion was determined by the method of the Mac-Master. It has been established that the level of damage of rabbits by spirochetosis and eimeriosis was, on average, $1155.17 \pm 184.87$ and $6668.97 \pm 284.16$ pathogens in $1 \mathrm{~g}$ of feces. The count of T- and B-lymphocytes was determined by the method of spontaneous rosette-formation with sheep erythrocytes. Parasitizing the association of pathogens Treponema cuniculi and Eimeria sp. was revealed a high number of leukocytes (1.22 times, $P<0.001)$, which increased mainly due to lymphocytes, which were 1.45 times higher $(P<0.001)$, as well as neutrophilic metamyelocytes 1.48 times $(P<0.05)$, eosinophils -1.68 times $(P<0.001)$ and basophils -1.57 times $(P<0.001)$ compared with similar blood parameters of healthy animals. In the blood of sick rabbits, the absolute number of T-lymphocytes (1.56 times, $P<0.001)$ and B-lymphocytes (3.02 times, $P<0.001)$ was significantly higher in comparison with a low number of O-lymphocytes (3.46 times, $P<0.001)$ compared with the control. This indicates the redistribution of lymphocytes to cells that carry $T$ and B lymphocyte receptors on the plasma membrane. The absolute number of T-lymphocytes became high due to T-helpers, which in these animals were higher both in absolute (1.87 times, $P<0.001)$ and percentage (by $9.18 \%, P<0.001$ ) compared to control. Moreover, the percentage of T-suppressors in the blood of rabbits of the experimental group was significantly lower on $5.46 \%(P<0.05)$ compared with the same blood count of healthy animals. Such a redistribution of the T-cell population in the peripheral blood of this group of rabbits led to an increase in the immunoregulatory index by 1.64 times $(P<0.01)$ than in healthy ones. High IRI and the number of Tactive lymphocytes (by $28.23 \%, P<0.05$ ) in the blood of rabbits with parasitism of the association of pathogens Treponema cuniculi and Eimeria sp. indicate increased immune system tension.

Key words: spirochetosis and eimeriosis, leukogram, T-lymphocyte, B-lymphocyte, O-lymphocyte, T-helper, T-suppressor, T-active lymphocyte.

\section{Клітинний імунітет кролів за впливу асоціації паразитів (Treponema cuniculi i Eimeria sp.)}

Ю.В. Дуда

Дніпровський державний аграрно-економічний університет, м. Дніпро, Україна

Унікальність протипаразитарного імунітету настільки велика, що, незважаючи на величезну кількість досліджень, ще недостатньо інформації про фактори, шео сприяють прояву особливостей імунітету за зміманих паразитарних хворобах кролів. Тому 
питання впливу асоиіації збудників Trеропета cuniculi та Eimeria sp. на показники клітинного імунітету кролів є актуальним. Дослідження проведено на 59 кролях-самиях 3-5-місячного віку каліфорнійської породи, відібраних за принципом аналогів. Тварин утримували в сітчастих одноярусних клітках у приміщенні, згідно з чинними ветеринарно-санітарними нормами. Тварини були поділені на дві групи: контрольні тварини (здорові тварини), дослідні (хворі тварини). Інтенсивність інвазії кролів визначали за методом Мак-Мастера. Тварини були поділені на дві групи: контрольні тварини (здорові тварини) та дослідні (хворі тварини). За результатами проведених досліджень встановлено, щьо рівень ураження кролів спірохетами і еймеріями склала в середньому відповідно 1155,17 \pm 184,87 збудників та 6668,97 \pm 284,16 оочист в 1 г фекалій. Загальну кількість T- та B-лімфоцитів визначали методом спонтанного розеткоутворення з еритроцитами барана. За паразитування асоціації збудників Ттеропета сипісиі та Eimeria sp. виявлено високу кількості лейкочитів (в 1,22 разу, $P<0,001)$, що зросла в основному за рахунок лімфочитів, які були вищі в 1,45 разу $(P<0,001)$, а також паличкоядерних нейтрофілів - в 1,48 разу $(P<0,05)$, еозинофілів - в 1,68 разу $(P<0,001)$ та базофілів - в 1,57 разу $(P<0,001)$, порівняно з аналогічними показниками крові здорових тварин. У крові хворих кролів встановлено вірогідно вищу абсолютну кількість Т-лімфоцитів (в 1,56 разу, $P<0,001)$ та В-лімфочитів (в 3,02 разу, $P<0,001)$ на фоні низької кількості О-лімфочити (в 3,46 разу, $P<0,001)$ порівняно з контролем. Це свідчить про перерозподіл лімфочитів на клітини, які несуть на плазматичній мембрані рецептори $T$ i В-лімфоцитів. Абсолютна кількість Т-лімфоцитів стала високою за рахунок T-хелперів, які у ичх тварин були вищчии як в абсолютному (в 1,87 разу, $P<0,001)$, так у відсотковому значенні (на 9,18\%, $P<$ 0,001) порівняно з контролем. При иььому відсоткова кількість Т-супресорів у крові кролів дослідної групи була достовірно нижчою на 5,46\% (P<0,05) порівняно з аналогічним показником крові здорових тварин. Такий перерозподіл популяиії Т-клітин у периферичної крові даної групи кролів зумовив зростання імунорегуляторного індексу в 1,64 разу (P < 0,01), ніж у здорових. Високі IPI та кількість Т-активних лімфоцитів (на 28,23\%, P < 0,05) у крові кролів за паразитування асоціації збудників Тгеропета сипісиі та Eітегіа sp. вказують на підвищення напруженості імунної системи.

Ключові слова: спірохетоз і еймеріоз, лейкограма, Т-лімфоцит, В-лімфочит, О-лімфочит, Т-хелпер, Т-супресор, Т-активний лімфочит.

\section{Вступ}

В Україні за декілька останніх років зросла кількість поголів'я кролів, у тому числі за рахунок завезених $з$ інших країн. Це своєю чергою призвело до виникнення, а далі й до спалаху хвороб, що тривалий час не реєстрували в країні, таких як спірохетоз. Це захворювання нашарувалось на еймеріоз, який спостерігався у багатьох областях України. Змішані паразитарні хвороби, за даними вчених, мають широке поширення в кролівничих господарствах і завдають вагомих економічних збитків цій галузі (Manzhos et al., 2007; Galimova et al., 2011). Вивчення імунітету, особливо клітинної ланки за цих паразитозів кролів як в дрібних, так і у великих спеціалізованих фермах, має актуальне науково-практичне значення, оскільки це дає можливість проведення своєчасної діагностики асоціативних хвороб кролів (Duda et al., 2019).

Імунітет за паразитарних хвороб має ряд особливостей, які обумовлені взаємовідносинами в системі паразит-хазяїн. Вченими виявлено, що паразити, одного разу “поселившись" в організм хазяїна, можуть довгі роки проживати в ньому, залишаючись при цьому малопомітними або непомітними зовсім (Daugalieva et al., 1996; Daugalieva, 2000; Duda, 2019). Виявляється, що “в процесі еволюції у паразитів виробилися ефективні механізми “маскування” власних антигенів і механізми ослаблення імунної відповіді з боку організму хазяїна за рахунок імуносупресії i включення аутотолерантності (Grishina, 2016). Як показали дослідження, таких “механізмів сформувалося безліч: і виборча локалізація паразита усередині клітини для зниження контакту з імунною системою хазяїна, і антигенна варіабельність в одній або в різних популяціях, і вбудовування у власні покривні оболонки антигенів хазяїна (антигенна мімікрія), і екранізація своїх поверхневих антигенів продуктами хазяїна" (Daugalieva, 2000; Grishina, 2016). Крім цього, гельмінти виробили і фізіологічні механізми регуляції гомеостазу та імунітету хазяїна. Так, “розвиток імунодепресії у хазяїна може відбуватися за рахунок продукції розчинних субстанцій для інактивації комплементу, для блокування антитіл, для зупинки проліферації лімфоцитів і зміни їхніх функцій, для дегрануляції тучних клітин, для стимуляції продукції клітин-супресорів" (Daugalieva \& Filippov, 1991; Daugalieva, 2000; Ezdakova et al., 2001; Kaljuzhnyj, 2001; Ezdakova et al., 2002; Kaljuzhnyj, 2002; Arisov, 2003; Bessonov, 2004; Hudov \& Larionov, 2004; Kisera et al., 2019). У багатьох гельмінтів, адаптованих до певного хазяїна, виявлені так звані еклепсівні антигени, які подібні за складом 3 антигенами хазяїна (Daugalieva, 2000; Sergiev \& Pal'cev, 2008; Grishina, 2016).

Унікальність протипаразитарного імунітету настільки велика, що, незважаючи на величезну кількість досліджень, ще недостатньо знань факторів, що сприяють прояву особливостей імунітету за змішаних паразитарних хворобах кролів. Тому питання впливу асоціації збудників Treponema cuniculi та Eimeria sp. на показники клітинного імунітету кролів $€$ актуальним.

Метою нашої роботи було вивчити вплив асоціації збудників Treponema cuniculi та Eimeria sp. на показники клітинного імунітету кролів.

\section{Матеріал і методи досліджень}

Робота виконувалась впродовж 2015-2018 pp. Експериментальна частина роботи виконана в ТОВ “Олбест" Дніпропетровської області та ТОВ “Кроликофф Плюс” Черкаської області, в яких використовують кліткове утримання тварин з додержанням всіх зоогігієнічних вимог і збалансованим раціоном годівлі. Лабораторні дослідження проводили в лабораторіях кафедри паразитології та ветсанекспертизи Дніпровського державного агроекономічного університету.

Для дослідів були відібрані аналогові групи кролів-самців 3-5-місячного віку каліфорнійської поро- 
ди. 3 метою визначення рівня ураженості кролів їх екскременти досліджували за методом Мак-Мастера. Тварини були поділені на дві групи: контрольні тварини (здорові тварини) та дослідні (хворі тварини).

За результатами проведених досліджень встановлено, що рівень ураження кролів спірохетами і еймеріями склала в середньому відповідно $1155,17 \pm$ 184,87 збудників та $6668,97 \pm 284,16$ ооцист в 1 г фекалій.

Загальну кількість Т-лімфоцитів визначали методом спонтанного розеткоутворення 3 еритроцитами барана (Cheredeev, 1976; Vlizlo et al., 2012). Число Т-клітин 3 переважно супресорною активністю (Т-супресори) - шляхом віднімання числа теофілінрезистентних Т-клітин (Т-хелпери) від загального числа Т-лімфоцитів. Імунорегуляторний індекс (IPI) розраховували як співвідношення теофілінрезистентних Т-клітин до теофілінчутливих. Визначення кількості В-лімфоцитів проводили методом комплементарного розеткоутворення (Cheredeev, 1976; Sitailo et al., 2000). Число О-клітин підраховували відніманням від 100\% суми загальної кількості Т-лімфоцитів та Влімфоцитів. Розетки, які утворилися в процесі реакцій, фіксували глютаровим альдегідом, а потім на предметних скельцях готували мазки. Готові мікропрепарати фіксували етанолом та фарбували за Рома-
новським-Гімзою. Результати реакцій оцінювали шляхом підрахунку під мікроскопом 200 лімфоцитів. За розетку рахували лімфоцит, що приєднав 3 і більше еритроцитів.

При роботі 3 тваринами дотримувалися вимог “Свропейської конвенції щодо захисту хребетних тварин, які використовуються в експерименті та інших наукових цілях" (Страсбург, 18.03.1986 р.). Статистичну обробку експериментальних результатів для визначення біометричних показників (середні значення та їх похибки, порівняння середніх значень за критерієм Стьюдента) здійснювали 3 використанням програми Microsoft Excel-16.

\section{Результати та їх обговорення}

За паразитування асоціації збудників Treponema cuniculi та Eimeria sp. в організмі кролів відбуваються певні зміни морфологічних показників крові (табл. 1). Так, в інвазованих тварин виявлено високу кількості лейкоцитів (в 1,22 разу, Р <0,001), що зросла в основному за рахунок лімфоцитів, які були вищі в 1,45 разу (P $<0,001)$, а також паличкоядерних нейтрофілів - в 1,48 разу $(\mathrm{P}<0,05)$, еозинофілів - в 1,68 разу $(\mathrm{P}<$ $0,001)$ та базофілів - в 1,57 разу $(\mathrm{P}<0,001)$, порівняно із аналогічними показниками крові здорових тварин.

Таблиця 1

Лейкоцитарна формула крові кролів за асоціації збудників Treponema cuniculi та Eimeria sp., $\mathrm{M} \pm \mathrm{m}$

\begin{tabular}{lcc}
\hline \multicolumn{1}{c}{ Показники } & \multicolumn{2}{c}{ Групи тварин } \\
\cline { 2 - 3 } & Здорові (контроль), $\mathrm{n}=32$ & Хворі (дослід), $\mathrm{n}=27$ \\
\hline Лейкоцити, Г/л & $5,75 \pm 0,30$ & $7,03 \pm 0,18^{* * *}$ \\
Лімфоцити, Г/л & $2,93 \pm 0,16$ & $4,24 \pm 0,17^{* * *}$ \\
Сегментоядерні нейтрофіли, Г/л & $1,93 \pm 0,16$ & $1,47 \pm 0,09$ \\
Паличкоядерні нейтрофіли, Г/л & $0,25 \pm 0,02$ & $0,37 \pm 0,05^{*}$ \\
Еозінофіли, Г/л & $0,28 \pm 0,03$ & $0,47 \pm 0,03^{* * *}$ \\
Моноцити, Г/л & $0,22 \pm 0,03$ & $0,24 \pm 0,03$ \\
Базофіли, Г/л & $0,14 \pm 0,01$ & $0,22 \pm 0,02^{* * *}$ \\
\hline
\end{tabular}

Примітка: * $\mathrm{P}<0,05 ; * * * \mathrm{P}<0,001$ порівняно зі здоровими тваринами

В лейкограмі хворих кролів, що показана на рисунку 1, відмітили відносний лімфоцитоз (на 8,66\%, $\mathrm{P}<0,001)$ та знижений рівень відсотка сегментоядерних нейтрофілів (на $11,33 \%$ ( $<<0,001)$, ніж у здорових, на фоні високої кількість палочкоядерних нейтрофілів. Такий характерний зсув формули нейтрофілів ліворуч, на нашу думку, свідчить про напруженість й інтенсивність запальної реакції в результаті паразитування асоціації збудників трепонем і еймерій.

Аналіз лекоцитарної формули показав, що у хворих кролів, порівняно 3 клінічно здоровими, встановлено як відносну, так і абсолютну еозинофілію - відповідно в 1,39 разу $(\mathrm{P}<0,001)$ та 1,68 разу $(\mathrm{P}<0,001)$ порівняно з показниками контролю.

Еозинофілія при паразитозах не є ознакою приєднання алергійних реакцій, а вказує на напруженість антипаразитарного імунітету, в якому важливу роль відіграють тучні клітини, гістамін і еозинофіли, які $є$ основними фагоцитами, що здійснюють руйнування паразита (Shevkopljas \& Lopatin, 2008).

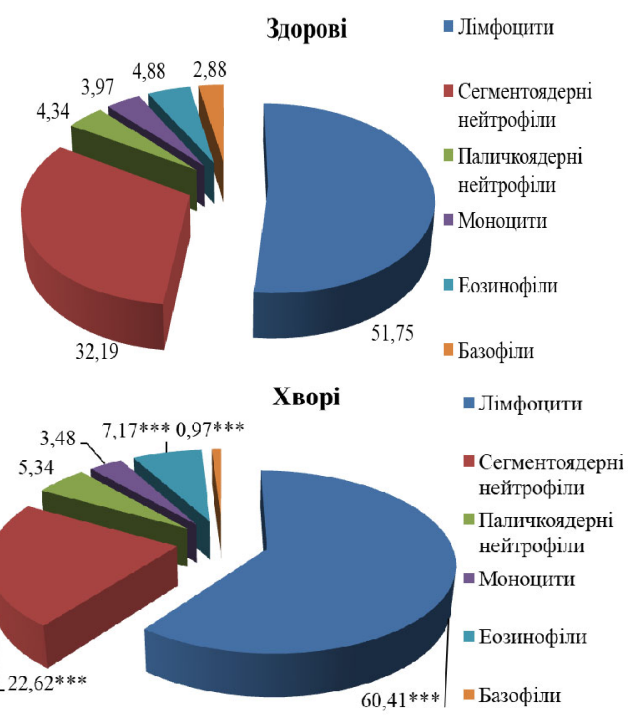

Примітка: ***P < 0,001 порівняно зі здоровими тваринами

Рис.1. Лейкограма кролів за асоціації збудників Treponema cuniculi та Eimeria sp. 
Базофільні гранулоцити за функціональною активністю відповідають тучним клітинам. При активації ефекторного механізму, опосередкованого тучними клітинами, базофіли крові активуються й мігрують до вогнища запалення, де здійснюють вивільнення гістаміну й інших біологічно активних речовин. Функціональна подібність до тучних клітин пояснює тісну співпрацю базофілів крові з еозинофільними гранулоцитами (Kazmirchuk, 2007). Тому вказані показники часто зазнають синхронізації, що спостерігається і в наших дослідах, де у хворих кролів базофіли були теж високими у відсотковому і в абсолютному значенні відповідно в 1,10 разу $(\mathrm{P}<0,001)$ та 1,57 разу
( $<<0,001)$, ніж у здорових тварин.

Отже, отримані дані свідчать про глибокі фізіологічні порушення, пов'язані зі змінами морфологічного складу крові кролів за паразитування асоціації збудників Treponema cuniculi та Eimeria sp.

Під час наших досліджень встановлено, що у спонтанно заражених кролів відбуваються істотні зміни і показників клітинного імунітету, зокрема кількості популяцій Т- і В-лімфоцитів (табл. 2). Т-лімфоцити беруть участь в реакціях клітинного імунітету, а В-лімфоцити, трансформуючись у плазматичні клітини, які синтезують антитіла, обумовлюють гуморальну імунну відповідь (Haitov \& Il'inoj, 2009).

\section{Таблиця 2}

Показники клітинного імунітету кролів за впливу асоціації збудників Treponema cuniculi та Eimeria sp., M \pm m

\begin{tabular}{|c|c|c|c|}
\hline \multirow{2}{*}{\multicolumn{2}{|c|}{ Показники }} & \multicolumn{2}{|c|}{ Групи тварин } \\
\hline & & \multirow{2}{*}{$\frac{\text { Здорові (контроль), } \mathrm{n}=32}{1,69 \pm 0,09}$} & \multirow{2}{*}{$\frac{\text { Хворі (дослід), } \mathrm{n}=27}{2,63 \pm 0,11 * * *}$} \\
\hline & Г/л & & \\
\hline 1-л1мфоцити & $\%$ & $58,29 \pm 1,91$ & $62,00 \pm 1,90$ \\
\hline \multirow{2}{*}{ В-лімфоцити } & Г/л & $0,45 \pm 0,03$ & $1,36 \pm 0,07 * * *$ \\
\hline & $\%$ & $15,21 \pm 0,37$ & $32,13 \pm 1,11 * * *$ \\
\hline \multirow{2}{*}{ Т-хелпери } & Г/л & $0,93 \pm 0,06$ & $1,74 \pm 0,09 * * *$ \\
\hline & $\%$ & $31,82 \pm 1,03$ & $41,00 \pm 1,39 * * *$ \\
\hline \multirow{2}{*}{ Т-супресори } & Г/л & $0,76 \pm 0,06$ & $0,90 \pm 0,07$ \\
\hline & $\%$ & $26,46 \pm 1,82$ & $21,00 \pm 1,32^{*}$ \\
\hline IPI & & $1,39 \pm 0,12$ & $2,28 \pm 0,21 * *$ \\
\hline \multirow{2}{*}{ Т-активні } & Г/л & $1,24 \pm 0,11$ & $1,59 \pm 0,08^{*}$ \\
\hline & $\%$ & $41,89 \pm 2,56$ & $37,52 \pm 1,08$ \\
\hline \multirow{2}{*}{ О-лімфоцити } & Г/л & $0,83 \pm 0,09$ & $0,24 \pm 0,03 * * *$ \\
\hline & $\%$ & $26,50 \pm 1,95$ & $5,86 \pm 0,64 * * *$ \\
\hline
\end{tabular}

Примітка: * $\mathrm{P}<0,05 ; * * \mathrm{P}<0,01 ; * * * \mathrm{P}<0,001$ порівняно зі здоровими тваринами

У крові хворих кролів відмічали вірогідно $(\mathrm{P}<0,001)$ вищу абсолютну кількість Т-лімфоцитів та В-лімфоцитів відповідно в 1,56 разу та 3,02 разу порівняно $з$ контролем. Абсолютна кількість Т-лімфоцитів стала високою за рахунок Т-хелперів, які у цих тварин були вищими як в абсолютному (в 1,87 разу, $\mathrm{P}<0,001$ ), так у відсотковому значенні (на 9,18\%, $\mathrm{P}<0,001)$ порівняно $з$ контролем. Оскільки Т-хелпери $\epsilon$ помічниками імунної відповіді, клітинами, що регулюють силу імунної відповіді організму на чужорідний антиген, контролюючи постійність внутрішнього середовища організму (антигенний гомеостаз) і зумовлюючи підвищене вироблення антитіл, то збільшення їхньої кількості, на нашу думку, свідчить про гіперактивність імунітету. При цьому відсоткова кількість Т-супресорів у крові кролів дослідної групи була достовірно нижчою на 5,46\% (P < 0,05) порівняно 3 аналогічним показником крові здорових тварин. Такий перерозподіл популяції Т-клітин у периферичної крові даної групи кролів зумовив зростання співвідношення Т-хелперів і Т-супресорів - імунорегуляторного індексу (IPI) - в 1,64 разу ( $<0,01)$, ніж у здорових. Підвищення співвідношення нерідко відзначається в гострій фазі різних запальних захворювань (Kazmirchuk, 2007). Цей факт підтверджує висока кількість Т-активних лімфоцитів у крові хворих кролів (на 28,23\%, Р < 0,05), проти аналогічного показника клінічно здорових тварин.
Одним із показників імунограми є О-лімфоцити, які були вірогідно (Р $<0,001)$ низькими в 3,46 разу (в абсолютному значенні) та на 20,64\% (у відсотковому значенні) в крові кролів дослідних груп порівняно 3 контролем. Це свідчить про перерозподіл лімфоцитів на клітини, які несуть на плазматичній мембрані рецептори Т і В-лімфоцитів.

Отримані нами дані збігаються з результатами інших вчених, які також відмітили, що Т- і В- лімфоцити збільшувалися в період загострення монопаразитозів, окремо за еймеріозу (Irgasheva, 1985; Pakandl et al., 2008) та спірохетозу (Giacani et al., 2004; Duda, 2019).

Причиною високої кількості Т-, В-лімфоцитів, Т-хелперів та Т-активних лімфоцитів на фоні низької кількості Т-супресорів і О-лімфоцитів у крові хворих кролів, на нашу думку, є відповідь на посилення антигенної стимуляції в запальному процесі.

\section{Висновки}

За паразитування асоціації збудників Treponema cuniculi та Eimeria sp. виявлено високу кількості лейкоцитів (в 1,22 разу, Р < 0,001), що зросла в основному за рахунок лімфоцитів, які були вищі в 1,45 разу (P $<0,001)$, а також паличкоядерних нейтрофілів - в 1,48 разу $(\mathrm{P}<0,05)$, еозинофілів - в 1,68 разу $(\mathrm{P}<0,001)$ та базофілів - в 1,57 разу $(\mathrm{P}<0,001)$ порів- 
няно зі аналогічними показниками крові здорових тварин.

У крові хворих кролів встановлено вірогідно вищу абсолютну кількість Т-лімфоцитів (в 1,56 разу, $\mathrm{P}<$ 0,001) та В-лімфоцитів (в 3,02 разу, Р < 0,001) на фоні низької кількості О-лімфоцитів (в 3,46 разу, Р < 0,001) порівняно з контролем. Це свідчить про перерозподіл лімфоцитів на клітини, які несуть на плазматичній мембрані рецептори Т- і В-лімфоцитів. Абсолютна кількість Т-лімфоцитів стала високою за рахунок Т-хелперів, які у цих тварин були вищими як в абсолютному (в 1,87 разу, $\mathrm{P}<0,001)$, так у відсотковому значенні (на 9,18\%, Р <0,001) порівняно з контролем. При цьому відсоткова кількість Т-супресорів у крові кролів дослідної групи була достовірно нижчою на $5,46 \%(\mathrm{P}<0,05)$ порівняно з аналогічним показником крові здорових тварин. Такий перерозподіл популяції Т-клітин у периферичної крові даної групи кролів зумовив зростання імунорегуляторного індексу в 1,64 разу (Р $<0,01)$, ніж у здорових. Високі IPI та кількість Т-активних лімфоцитів (на 28,23\%, Р < 0,05) у крові кролів за паразитування асоціації збудників Treponema cuniculi та Eimeria sp. вказують на підвищення напруженості імунної системи.

Перспективи подальших досліджень. Визначення змін рівня імуноглобулінів A, G, М за впливу асоціації збудників Treponema cuniculi та Eimeria sp.

\section{References}

Arisov, M.V. (2003). Immunnyj status ovec, spontanno zarazhennyh nematodami i cestodami. Teorija i praktika bor'by s parazitarnymi boleznjami. Materialy dokladov nauchnoj konferencii, 33-35 (in Russian).

Bessonov, A.S. (2004) Immunitet $\mathrm{i}$ immunosupressija pri parazitarnyh boleznjah. Trudy VIGIS, 40, 44-53 (in Russian).

Cheredeev, A.N. (1976). Kolichestvennaja i funkcional'naja ocenka T- i V-sistem immuniteta cheloveka. Obshhie voprosy patologi, 4, 126-160 (in Russian).

Daugalieva, Je.H. (2000). Immunitet pri gel'mintozah. Trudy VIGIS, 36, 27-50 (in Russian).

Daugalieva, Je.H., Kurochkina, K.G., \& Arinkin, A.V. (1996). Osobennosti immuniteta pri gel'mintozah. Veterinarija, 7, 37-38 (in Russian).

Daugalieva, Je.X., \& Filippov, V.V. (1991) Immunnyj status i puti ego korrekcii pri gel'mintozah sel'skohozjajstvennyh zhivotnyh. Moskva. Agropromizdat (in Russian).

Duda, Y., Kuneva, L., \& Shevchik, R. (2019). The effect of cysticercosis invasion on the cellular immunity of rabbits. Scientific horizons, 8(81), 36-41. doi: 10.33249/2663-2144-2019-81-8-36-41 (in Ukrainian).

Duda, Y.V. (2019). Klitynnyi imunitet kroliv za vplyvu Treponema cuniculi. Naukovo-tekhnichnyi biuleten DNDKI veterynarnykh preparativ ta kormovykh dobavok i Instytutu biolohii tvaryn NAAN, 20(2), 223-229. doi: 10.36359/scivp.2019-20-2.28 (in Ukrainian).
Duda, Y.V. (2019). Nonspecific reactivity of the rabbits organism when exposed to cysticercosis. Scientific Messenger of Lviv National University of Veterinary Medicine and Biotechnologies. Series: Veterinary sciences, 21(94), 132-135. doi: 10.32718/nvlvet9424 (in Ukrainian).

Ezdakova, I.Ju., Borzenko, E.V., Feoktistova, T.A., \& Fedorov, Ju.N. (2002) Kolichestvennoe opredelenie immunoglobulinov A-klassa v biologicheskih zhidkostjah krupnogo rogatogo skota metodami immunofermentnogo analiza i radial'noj immunodiffuzii. Sel'skohozjajstvennaja biologija, 2, 118-122 (in Russian).

Ezdakova, I.Ju., Fedorov, Ju.N., \& Zhadanov, A.I. (2001) Dinamika kolichestva T-kletok i ih vzaimodejstvie $\mathrm{s}$ antigenpredstavljajushhimi kletkami $\mathrm{V}$ processe immunnogo otveta. Citologija, 43(9), 858 (in Russian).

Galimova, V.Z., Asabullina, I.I., \& Galiullina, A.M. (2011) Pokazateli krovi krolikov pri jejmerioze v associacii $\mathrm{s}$ infekcionnym stomatitom. Teorija i praktika bor'by $\mathrm{s}$ parazitarnymi boleznjami: Mat. nauchn. konf., 12, 124-126 (in Russian).

Giacani, L., Sun, E.S., Hevner, K., et al. (2004). Tpr homologs in Treponema paraluiscuniculi Cuniculi A strain. Infect Immun., 72(11), 6561-6576. doi: 10.1128/IAI.72.11.6561-6576.2004.

Grishina, E.A. (2016). Antigeny i metabolity gelmintov kak reguliruiushchie faktory protivoparazitarnogo immuniteta. Epidemiologiia i infektcionnye bolezni. Aktualnye voprosy, 2, 58-63 (in Russian).

Haitov, R.M., \& Il'inoj, N.I. (2009). Allergologija i immunologija: nacional'noe rukovodstvo. Moskva. GJeOTAR-Media (in Russian).

Hudov, G.N., \& Larionov, S.V. (2004). T-helpery i Tsupressory v krovi pri smeshannoj invazii loshadej // Sovremennye problemy immunogeneza, teorii i praktiki bor'by $\mathrm{s}$ parazitarnymi i infekcionnymi boleznjami sel'skohozjajstvennyh zhivotnyh: Materialy mezhdunarodnoj nauchnoprakticheskoj konferencii, posvjashhennoj 90-letiju so dnja rozhdenija professora H.V. Ajupova, 302-304 (in Russian).

Irgasheva, L.I. (1985). Klinicheskie priznaki i kartina krovi pri kokcidioze krolikov. Materialy 9 nauchnoprakticheskoj konferencii po voprosam intensifikacii sel'skogo hozjajstva v svete realizacii Prodovol'stvennoj programmy, 39-43 (in Russian).

Kaljuzhnyj, S.I. (2001). Dinamika T-E-ROK-limfocitov, T-helperov, Tsupressorov i V-EAS-limfocitov v krovi, limfaticheskih uzlah, selezenke i timuse pri kriptosporidioze porosjat. Sovremennye immunomorfologicheskie problemy razvitija zhivotnyh pri associativnyh infekcionno-invazionnyh zabolevanijah i ispold'zovanii dlja ih profilaktiki biologicheski aktivnyh produktov pchelovodstva, 183-185 (in Russian).

Kaljuzhnyj, S.I. (2002) Dinamika T-limfocitov i ego subpopuljacij V krovi porosjat, bol'nyh kriptosporidioznym zabolevaniem i metody ih 
korrekcii. Immunobiologicheskie, tehnologicheskie, jekonomicheskie faktory povyshenija proizvodstva produkcii sel'skogo hozjajstva, 133-138 (in Russian).

Kazmirchuk, V.Ie. (2007). Interpretatsiia leikohramy ta imunohramy zghidno z suchasnymy pozytsiiamy. Vnutrenniaia medytsyna,4(4). Available from: http://www.mif-ua.com/archive/article/2837 Ukrainian).

Kisera, Ya.V., Storchak, Yu.G., Gutyj, B.V., Bozhyk, L.Ya., Magrelo, N., Sus, Y., Dashkovskyy, O., Pryimych, V.I., Vus, U., Kit, L., Sachuk, R. (2019). Structural and functional features of the vermiform appendix at the tissue and cellular levels in rabbits after the introduction of immunobiological drugs. Ukrainian Journal of Ecology, 9(2), 217226. https://www.ujecology.com/abstract/structuraland-functional-features-of-the-vermiform-appendix-atthe-tissue-and-cellular-levels-in-rabbits-after-theintr-43902.html.

Manzhos, O.F., Peredera, R.V., \& Peredera, O.O. (2007) Biokhimichni pokaznyky syvorotky krovi pry eksperymentalnomu pechinkovomu eimeriozi kroliv. Visnyk DAU. Zhytomyr, 2(10), 1, 274-279 (in Ukrainian).
Pakandl, M., Hlásková, L., Nevečeřalová, M., Vodička, T., Salát, J., \& Mucksová, J. (2008). Immune response to rabbit coccidiosis: a comparison between infections with Eimeria flavescens and E. intestinalis. FOLIA PARASITOLOGICA, 55, 1-6. doi: 10.14411/fp.2008.001.

Sergiev, V.P., \& Pal'cev, M.A. (2008). Fiziologija parazitizma i problema biologicheskoj bezopasnosti. Moskva, Medicina (in Russian).

Shevkopljas, V.N., \& Lopatin, V.G. (2008). Vlijanie gel'mintozov na techenie immunologicheskih processov u zhivotnyh. Rossijskij parazitologicheskij zhurnal, (4), 94-101. Available from: https:/cyberleninka.ru/article/n/vliyanie-gelmintozovna-techenie-immunologicheskih-protsessov-uzhivotnyh (in Russian).

Sitailo, S.G., Elchaninova, T.I., Vasilenko Y.I. et al. (2000). Sovremennye metody otcenki immunnogo statusa Krivoy Rog (in Russian).

Vlizlo, V.V., Fedoruk, R.S., \& Ratych, I.B. (2012). Laboratorni metody doslidzhen $\mathrm{u}$ biolohii, tvarynnytstvi ta veterynarnii medytsyni. Dovidnyk. za red. Vlizla, V.V. Lviv. SPOLOM (in Ukrainian). 